\title{
Evaluation of Resistance to Some Pyrethroid and Organophosphate Insecticides and Their Underlying Impact on the Activity of Esterases and Phosphatases in House Fly, Musca domestica (Diptera: Muscidae)
}

\author{
Kanwal Ranian', Muhammad Kashif Zahoor ${ }^{1 *}$, Muhammad Asif Zahoor ${ }^{2}$, Hina Rizvi, \\ Azhar Rasul', Humara Naz Majeed ${ }^{4}$, Farhat Jabeen', Iqra Sarfraz ${ }^{1}$, \\ Muhammad Zulhussnain ${ }^{1}$, Bushra Riaz ${ }^{1}$, Atta Ullah ${ }^{1}$ \\ ${ }^{1}$ Department of Zoology, Government College University Faisalabad, Pakistan \\ ${ }^{2}$ Department of Microbiology, Government College University Faisalabad, Pakistan \\ ${ }^{3}$ Department of Environmental Sciences \& Engineering, Government College University Faisalabad, Pakistan \\ ${ }^{4}$ Department of Biochemistry, Government College Women University, Faisalabad, Pakistan
}

Received: 20 July 2018

Accepted: 23 September 2018

\begin{abstract}
Resistance development against some frequently used insecticides, i.e., deltamethrin $(1.5 \%$ EC), cypermethrin $(10 \% \mathrm{SC})$, permethrin $(0.5 \% \mathrm{WP})$ and DDVP $(50 \% \mathrm{EC})$ was evaluated against Musca domestica L. Insecticide bioassays were carried out against susceptible and resistant strains at 2.5, 5, 10, 20 and $40 \mu \mathrm{g} / \mu \mathrm{l}$ concentrations. Mortality data was recorded after 24, 48 and 72 hours. Resistance was monitored up to three generations and the flies with higher $\mathrm{LD}_{50}$ values than the $\mathrm{F} 1$ generation were considered resistant. $\mathrm{LD}_{50}$ values for Permethrin increased from $58.258 \mu \mathrm{g} / \mu \mathrm{l}$ to $85.1375 \mu \mathrm{g} / \mu 1$ with highest resistance ratio (RR) in F1 to F3. The lowest resistance ratio was observed with DDVP. Maximum inhibition in adult emergence was observed against DDVP. The inhibitory activity of Esterases; Acetylcholine and Phosphatases; ACP, AKP was recorded. Deltamethrin inhibited the maximum activity of AChE (50\%), whereas, DDVP caused maximum inhibition of acid phosphatases. The results suggested that house fly populations are more resistant to pyrethroids compared to organophosphate insecticides.
\end{abstract}

Keywords: Musca domestica, organophosphates, pyrethroids, enzyme inhibition, resistance

*e-mail: kashif.zahoor@gcuf.edu.pk 


\section{Introduction}

The house fly, Musca domestica belongs to order Diptera, family Muscidae. It is considered an important pest of humans and livestock [1]. Musca domestica is a general nuisance and is responsible for food contamination by transferring various contagious pathogens of diseases including bacillary dysentery, cholera, shigellosis, avian influenza and salmonellosis $[2,3]$. House flies are an economic concern to poultry and animal farms resulting in low milk production because cows spend additional energy in fending off these flies (fly worry) [3, 4].

Chemical control has been the primary method of control strategy since 1950's with organophosphates and pyrethroids frequently used [5]. Organophosphate pesticides are generally broad spectrum with esters of phosphoric acids, which affect the activity of neuromuscular enzyme acetylcholine-esterase. This enzyme is essential for normal body functioning of insects [6, 7]. Similarly, pyrethroid insecticides including Cypermethrin, Deltamethrin, and Permethrin are primary chemical insecticides used against many insect pests including house fly [8-10]. It is well established that the indiscriminate use of pesticides has resulted in the development of insect strains that are resistant to those insecticides [11]. The development of resistance is a potential threat to the future of insect control strategies [12]. Musca domestica, the common house fly, has been shown to develop resistance to insecticides [13, 14]. The monitoring of insecticide resistance through bioassays is a helpful tool to recognize resistant development to any insecticide or group of insecticides. Documentation of resistence, thus, helps in developing alternative solutions to devise better management strategies [15].

Metabolic degradation for many pyrethroids is reported through esterase-mediated metabolism and considered as one of the major resistance methods developed by insects [16-18]. Pyrethroid resistance in house flies is due to the insensitive acetylcholinesterase (AChE) as a defence mechanism to counter the effect of the insecticide $[19,20]$. AChE is also involved in the detoxification of synthetic insecticides to form less toxic metabolites [21, 22]. Resistant house flies show changed AChE activity, rendering it less sensitive to the inhibitors [23]. Furthermore, phosphatases are reported to be involved in various physiological mechanisms [24-26] and used as indicator enzymes to evaluate the damaging effects of numerous toxicants related to the physiological status of insect pests. Similarly, Alkalinephosphatases (AKP) are hydrolytic enzymes that detoxify many insecticides like the organophosphate group [27]. Insect growth regulators (IGRs) affect insects by regulating or inhibiting certain biochemical paths or routes necessary for growth and development. Insect pests exposed to IGRs possibly die due to irregular regulation of organ development or after an abnormal inhibition of a developmental stage [28].

Insecticide resistance is a major challenge to the management of house fly. Hence, the current study was conducted to evaluate the resistance of most frequently used pyrethroids and organophosphates against $M$. domestica. Biochemical response of insecticide resistance was also addressed focusing on the modified activities of esterases and phosphatases.

\section{Materials and Methods}

Musca domestica was collected in Faisalabad, Pakistan by sweep-netting and reared in the Entomology Lab of the Department of Zoology, Government College University Faisalabad, on artificial diet under optimum conditions of $28^{\circ} \mathrm{C} \pm 2^{\circ}$ and $60-70 \% \mathrm{RH}$ with $12 \mathrm{~L}$ : $12 \mathrm{D}$ (h) photoperiod. The collected fly samples (Fig. 1) were

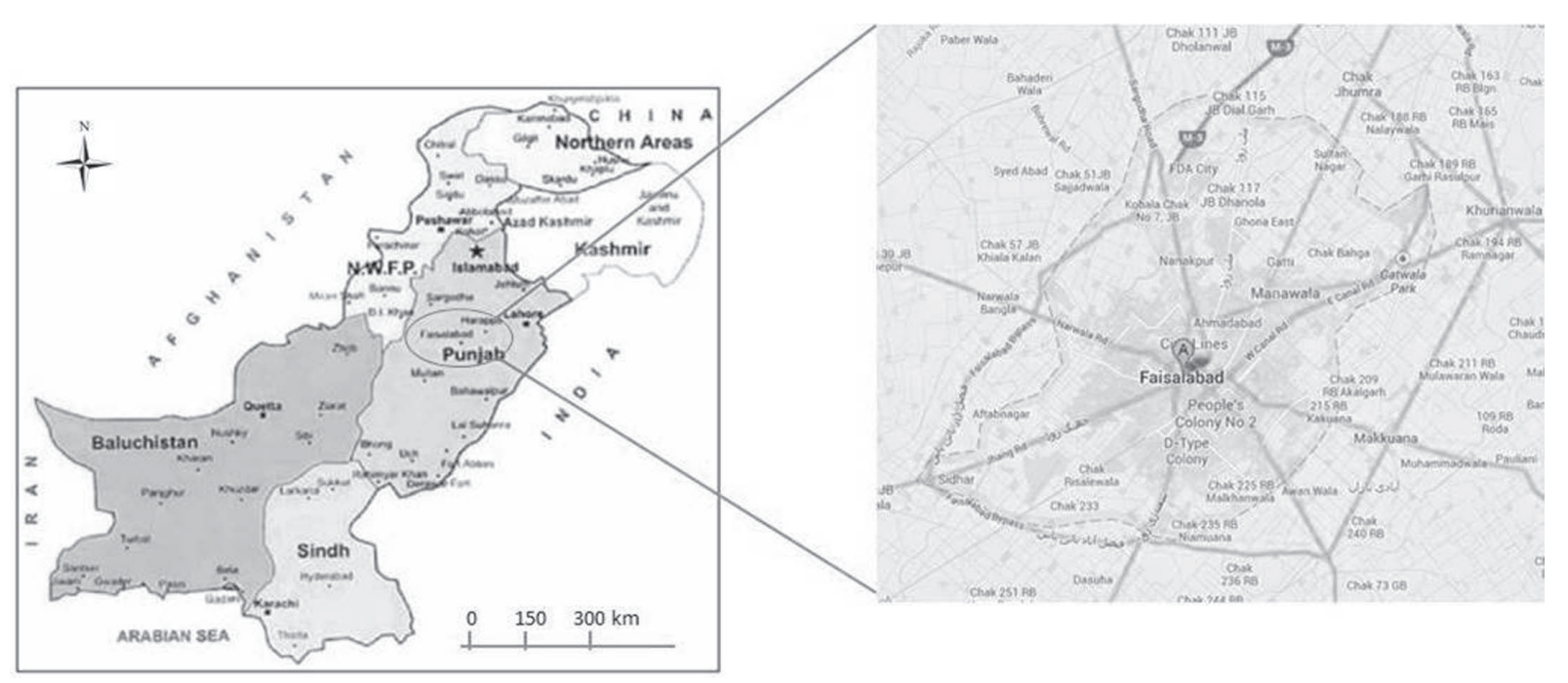

Fig. 1. The map showing the region and city where collection of house fly, $M$. domestica samples was made (taken and drawn from google.com). 
initially sorted out in two groups through PCR based on knockdown resistance ( $\mathrm{kdr}$ allele) against pyrethroids in VGSC gene (voltage-gated sodium channels) as described by Gomes et al. [18], Scott [19], Al-Deeb [29] and Sing et al.:[30]. Resistant populations were pooled and considered as a resistant strain used during the study. The susceptible population was referred to as the laboratory reference strain and was used as control.

Technical grade formulated pyrethroid insecticides: Cypermethrin (1.5\%EC), Deltamethrin (1.5\% w/v), Permethrin (0.5\%WP) and the organophosphate DDVP $(50 \% \mathrm{EC})$ were selected to evaluate the toxicity and further resistance through feeding bioassays. Twenty, 3-5-day-old flies were introduced into plastic containers $(250 \mathrm{ml})$ and were provided with two pieces of cotton dental wick (2 cm length) moistened with a $20 \%$ sugar:water solution containing different concentrations $(2.5,5,10,20$ and $40 \mu \mathrm{g} / \mu \mathrm{l})$ of an insecticide. The control plastic jar was given cotton wicks soaked in a $20 \%$ sugar solution without any toxicant [31,32]. Experiments were replicated three times under Completely Randomized Design (CRD). The $\mathrm{LD}_{50}$ values for $24 \mathrm{~h}, 48 \mathrm{~h}$, and $72 \mathrm{~h}$ were calculated using Finney's Probit analysis [14, 33].

Data regarding percentage mortality was recorded after $24 \mathrm{~h}, 48 \mathrm{~h}$ and $72 \mathrm{~h}$ of treatment. Mortality in control groups was also noted to obtain the corrected mortality according to Abbot's formula [34]. The corrected mortality data were subjected to ANOVA using Statistica 13.0 for Windows. The means were separated using Tuckey's HSD (Honest Significant Difference) test at a significance level of 0.05 . A value of $p<0.05$ was considered statistically significant.

$$
P=\frac{\mathrm{T}-\mathrm{C}}{100-\mathrm{C}} \times 100
$$

Here $\mathrm{P}$ is the $\%$ corrected mortality, $\mathrm{C}$ is the $\%$ mortality in the non-treated group and $\mathrm{T}$ is the $\%$ mortality in the treated group.

\section{Evaluation of Resistance of Pyrethroid and Organophosphate Insecticides in $M$. domestica}

For the detection of resistance, three generations of $M$. domestica were reared. After the adult mortality had been recorded after $72 \mathrm{~h}$, the flies that remained alive were allowed to complete their three generations. Twenty adult flies were used to evaluate the resistance after 48 hours feeding on the insecticide. Mortality data was recorded after 48 hours of insecticide treatment on the emerged flies of the F1 and F2 (parental) generations. The number of emerging flies was recorded after 2 weeks and meanwhile, the mortality was calculated [35]. The resistance level was measured in each successive generation in order to evaluate the increase in resistance level following the protocol of Singh \& Prakash [36]. The resistance ratios (Resistant/
Susceptible) were estimated by dividing the $\mathrm{LD}_{50}$ for resistant strain to the $\mathrm{LD}_{50}$ for the reference strain [32, $35,37]$.

\section{Bioassay for Growth Inhibitory Effects}

To assess the toxicity of IGR insecticides, larval bioassays were performed by following the methodology of Cetin et al. [38]. Five concentrations (2.5, 5, 10, 20 and $40 \mu \mathrm{g} / \mu \mathrm{l}$ ) of each insecticide was applied on $20 \mathrm{~g}$ culturing media. Twenty newly hatched $1^{\text {st }}$ instar larvae were introduced onto the treated media and allowed to complete the development. Time interval data was collected for stage to stage development; larvae to pupae and then pupae to the adult emergence in the F1 generation up to 30 days and was compared with the control.

\section{Quantitative Analysis of Esterases and Phosphatases Activity}

Flies that survived to the third generation were homogenized separately by adding $1.5 \mathrm{ml}$ ice-cold sodium phosphate buffer $(20 \mathrm{mM}$. pH up to 7.0$)$. The homogenate was then centrifuged at 8000 revolution per minutes at $4^{\circ} \mathrm{C}$ for 20 minutes and the supernatant was separated for the estimation of esterases (Acetylcholinesterases) and phosphatases (Acid Phosphatases and Alkaline Phosphatases) by following the methodology of Younes et al. [39].

The percentage inhibition of the enzyme activity by the test extracts was calculated as follows

$$
\begin{gathered}
\% \text { Enzyme inhibition }= \\
\frac{\text { OD of Control }- \text { OD of treated }}{\text { OD of Control }} \times 100
\end{gathered}
$$

\section{Results and Discussion}

\section{Evaluation of Resistance of Commonly Used Insecticides Against $M$. domestica}

The percentage mortality of $M$. domestica was recorded against five different concentrations of Cypermethrin, Deltamethrin, Permethrin and DDVP. With a $40 \mu \mathrm{g} / \mu \mathrm{l}$ concentration and $72 \mathrm{~h}$ of exposure period, DDVP showed the highest mean mortality $(98.33 \%)$ and significant results against $M$. domestica. On the other hand, lowest mean mortality percentage was observed with Permethrin (73.80\%) at the same exposure time. All tested insecticides caused maximum mortality at $72 \mathrm{~h}$ of exposure time period (Table 1). Overall, it was found that increased concentration caused increased mortality. In addition, prolonged exposure time also caused higher mortality. Moreover, Permethrin showed the highest $\mathrm{LD}_{50}$ value of $20.10 \mu \mathrm{g} / \mu \mathrm{l}$ at $72 \mathrm{~h}$ exposure followed by Deltamethrin 
Table 1 . Mean \% mortality of $M$. domestica by tested pyrethroid and organophosphate insecticides at various concentrations and different exposure time.

\begin{tabular}{|c|c|c|c|c|c|c|c|}
\hline \multirow{2}{*}{$\begin{array}{c}\text { Code } \\
\text { No. }\end{array}$} & \multirow{2}{*}{$\begin{array}{l}\text { Conc. } \\
\mu \mathrm{g} / \mu \mathrm{l}\end{array}$} & \multirow{2}{*}{ F-Value } & \multirow{2}{*}{ d.f } & \multirow{2}{*}{ P-value } & \multicolumn{3}{|c|}{ Mean Mortality with different time intervals } \\
\hline & & & & & 24 hours & 48 hours & 72 hours \\
\hline \multirow{5}{*}{ Permethrin } & 2.5 & 6.87 & 2 & 0.028 & 0.000000 & 0.000000 & $21.17 \pm 13.99 \mathrm{a}$ \\
\hline & 5.0 & 20.00 & 2 & 0.002 & $7.07 \pm 8.16 \mathrm{c}$ & $31.60 \pm 5.35 b$ & $35.17 \pm 3.18 \mathrm{a}$ \\
\hline & 10 & 35.22 & 2 & 0.001 & $10.57 \pm 5.40 \mathrm{c}$ & $17.67 \pm 2.89 b$ & $39.67 \pm 4.62 \mathrm{a}$ \\
\hline & 20 & 111.10 & 2 & 0.001 & $14.17 \pm 3.18 \mathrm{c}$ & $35.17 \pm 3.18 b$ & $54.00 \pm 3.46 \mathrm{a}$ \\
\hline & 40 & 285.62 & 2 & 0.001 & $16.00 \pm 0.00 \mathrm{c}$ & $58.00 \pm 0.00 \mathrm{~b}$ & $73.80 \pm 5.30 \mathrm{a}$ \\
\hline \multirow{5}{*}{ Cypermethrin } & 2.5 & 57.41 & 2 & 0.001 & $0.000000 \mathrm{c}$ & $14.17 \pm 3.18 b$ & $31.43 \pm 5.36 \mathrm{a}$ \\
\hline & 5.0 & 35.74 & 2 & 0.002 & $12.33 \pm 3.18 \mathrm{c}$ & $35.17 \pm 3.18 \mathrm{~b}$ & $49.03 \pm 8.14 \mathrm{a}$ \\
\hline & 10 & 82.85 & 2 & 0.001 & $35.17 \pm 3.18 \mathrm{c}$ & $52.67 \pm 5.51 \mathrm{~b}$ & $77.33 \pm 2.89 \mathrm{a}$ \\
\hline & 20 & 82.85 & 2 & 0.002 & $35.17 \pm 3.18 \mathrm{c}$ & $52.67 \pm 5.51 \mathrm{~b}$ & $77.33 \pm 2.89 \mathrm{a}$ \\
\hline & 40 & 20.26 & 2 & 0.002 & $45.67 \pm 8.08 \mathrm{c}$ & $66.80 \pm 8.12 b$ & $87.80 \pm 8.12 \mathrm{a}$ \\
\hline \multirow{5}{*}{ DDVP } & 2.5 & 95.19 & 2 & 0.000 & $0.0000 \pm 0.00 \mathrm{c}$ & $10.57 \pm 5.40 \mathrm{~b}$ & $38.70 \pm 2.94 \mathrm{a}$ \\
\hline & 5.0 & 148.77 & 2 & 0.000 & $0.0000 \pm 0.00 \mathrm{c}$ & $14.17 \pm 3.18 b$ & $54.43 \pm 6.18$ \\
\hline & 10.0 & 291.89 & 2 & 0.001 & $0.0000 \pm 0.00 \mathrm{c}$ & $35.17 \pm 3.18 b$ & $62.70 \pm 4.51 \mathrm{a}$ \\
\hline & 20.0 & 370.21 & 2 & 0.001 & $12.33 \pm 3.18 \mathrm{c}$ & $56.33 \pm 2.89 b$ & $77.33 \pm 2.89$ \\
\hline & 40.0 & 336.94 & 2 & 0.002 & $35.17 \pm 3.18 \mathrm{c}$ & $59.70 \pm 2.94 b$ & $98.33 \pm 2.89 \mathrm{a}$ \\
\hline \multirow{5}{*}{ Deltamethrin } & 2.5 & 39.08 & 2 & 0.002 & $11.67 \pm 7.64 \mathrm{c}$ & $35.00 \pm 5.00 \mathrm{~b}$ & $55.00 \pm 5.00 \mathrm{a}$ \\
\hline & 5.0 & 83.17 & 2 & 0.001 & $16.67 \pm 2.89 \mathrm{c}$ & $46.67 \pm 5.77 b$ & $58.33 \pm 2.89 \mathrm{a}$ \\
\hline & 10.0 & 37.50 & 2 & 0.003 & $25.00 \pm 5.00 \mathrm{c}$ & $58.33 \pm 7.64 b$ & $66.67 \pm 5.77 \mathrm{a}$ \\
\hline & 20.0 & 147.00 & 2 & 0.003 & $38.33 \pm 2.89 \mathrm{c}$ & $63.33 \pm 2.89 b$ & $78.33 \pm 2.89 a$ \\
\hline & 40.0 & 147.00 & 2 & 0.002 & $41.67 \pm 2.89 c$ & $66.67 \pm 2.89 b$ & $81.67 \pm 2.89 \mathrm{a}$ \\
\hline
\end{tabular}

with an $\mathrm{LD}_{50}$ of $9.53 \mu \mathrm{g} / \mu \mathrm{l}$. Cypermethrin and DDVP showed $\mathrm{LD}_{50}$ values of $4.36 \mu \mathrm{g} / \mu \mathrm{l}$ and $5.527 \mu \mathrm{g} / \mu \mathrm{l}$, respectively at $72 \mathrm{~h}$ exposure time (Table 2 ).

The toxicity of four tested insecticides and resistance ratios of three generations of house flies was recorded based on their $\mathrm{LD}_{50}$ values. Those insects with higher $\mathrm{LD}_{50}$ values were considered resistant in successive generations. Very low level to no resistance was found against DDVP when compared with Cypermethrin, Deltamethrin and Permethrin (Table 3). Resistance ratios (RR) ranged between 0.9760.975 in the case of DDVP. With Deltamethrin and Cypermethrin, moderate level of resistance (RRs) was found with a range between 1.034-1.182 and 1.10591.225 , respectively. Maximum resistance was found in Permethrin with RRs ranging between 1.299-1.461. Nevertheless, a reduction in \% age mortality was also observed in successive generations for Permethrin, Deltamethrin and Cypermethrin. The regression line slopes were found similar for all the generations against Deltamethrin, Cypermethrin, Permethrin and DDVP with p-value $<0.05$ (Fig. 2 and Table 3).

\section{Mean Adult Emergence and Percent Progeny Inhibition of $M$. domestica}

Mean adult emergence and progeny inhibition were determined. DDVP caused maximum inhibition at $2.5 \mu \mathrm{g} / \mu \mathrm{l}$ concentration when compared to the other insecticides (59.33\%), followed by Cypermethrin (58.33\%), and Permethrin (53.33\%), respectively. The lowest inhibitory activity was observed with Deltamethrin (48.33\%). The lowest percentage of adult emergence (17.67\%) was shown by DDVP at a $40 \mu \mathrm{g} / \mu \mathrm{l}$ concentration, which inhibited the F1 population by $82.33 \%$. Similarly, Cypermethrin caused $80 \%$ adult inhibition and $20 \%$ adult emergence; Permethrin induced $80.67 \%$ inhibition and $19.33 \%$ adult emergence; while Deltamethrin caused $75 \%$ adult emergence and 25\% inhibition (Table 4).

\section{Enzyme Bioassay}

Cypermethrin, Deltamethrin, Permethrin and DDVP were also tested at three concentrations $(2.5,10$, and $40 \mu \mathrm{g} / \mu \mathrm{l})$ for their effect on the activity of Esterases 
Table 2. Toxicity of tested pyrethroid and organophosphate insecticides against $M$. domestica after 24, 48 and 72 hours of exposure time.

\begin{tabular}{|c|c|c|c|c|c|c|c|c|}
\hline Pesticide & $\begin{array}{l}\text { Exop. } \\
\text { Time }\end{array}$ & $\mathrm{N}$ & $\mathrm{LD}_{50}$ & Slope + SE & $\mathrm{X}^{2}$ & Df & $\mathrm{SE}$ & $\mathrm{p}$ Value \\
\hline \multirow[t]{3}{*}{ Permethrin } & 24 & 20 & $\begin{array}{c}85.1375 \\
(61.0016 \pm 165.704) \\
\end{array}$ & $\begin{array}{c}0.0196074 \\
+0.0054831 \\
\end{array}$ & 9.3705 & 3 & 18.8184 & 0.025 \\
\hline & 48 & 20 & $\begin{array}{c}33.0004 \\
(29.4130 \pm 37.8084)\end{array}$ & $\begin{array}{c}0.0449377 \\
+0.0046953\end{array}$ & 14.6386 & 3 & 2.07405 & 0.002 \\
\hline & 72 & 20 & $\begin{array}{c}20.1069 \\
(16.9851 \pm 23.7781)\end{array}$ & $\begin{array}{c}0.0373187 \\
+0.0044735\end{array}$ & 11.2009 & 3 & 1.67891 & 0.011 \\
\hline \multirow[t]{3}{*}{ Cypermethrin } & 24 & 20 & $\begin{array}{c}36.2375 \\
(31.0452 \pm 44.3310)\end{array}$ & $\begin{array}{c}0.0322737 \\
+0.0044740 \\
\end{array}$ & 41.4469 & 3 & 3.18306 & 0.000 \\
\hline & 48 & 20 & $\begin{array}{c}18.9100 \\
(15.3059 \pm 23.0703)\end{array}$ & $\begin{array}{c}0.0315766 \\
+0.0043692\end{array}$ & 24.4804 & 3 & 1.90163 & 0.000 \\
\hline & 72 & 20 & $\begin{array}{c}4.36354 \\
(0.421237 \pm 7.34286)\end{array}$ & $\begin{array}{c}0.0437169+ \\
0.0053817\end{array}$ & 29.4914 & 3 & 1.69692 & 0.000 \\
\hline \multirow[t]{3}{*}{ DDVP } & 24 & 20 & $\begin{array}{c}47.1516 \\
(42.4189 \pm 54.3306) \\
\end{array}$ & $\begin{array}{c}0.0574333+ \\
0.0073487 \\
\end{array}$ & 9.9447 & 3 & 2.87894 & 0.019 \\
\hline & 48 & 20 & $\begin{array}{c}26.9337 \\
(23.4027+31.6132) \\
\end{array}$ & $\begin{array}{c}0.0372045+ \\
0.0044175 \\
\end{array}$ & 25.4148 & 3 & 2.01704 & 0.000 \\
\hline & 72 & 20 & $\begin{array}{c}5.52724 \\
(2.55867 \pm 7.89061) \\
\end{array}$ & $\begin{array}{c}0.0540393+ \\
0.0064286 \\
\end{array}$ & 4.44034 & 3 & 1.31418 & 0.018 \\
\hline \multirow[t]{3}{*}{ Deltamethrin } & 24 & 20 & $\begin{array}{c}43.1706 \\
(35.0711 \pm 58.8665)\end{array}$ & $\begin{array}{c}0.0239581+ \\
0.0043813\end{array}$ & 7.86628 & 3 & 5.37054 & 0.049 \\
\hline & 48 & 20 & $\begin{array}{c}9.53950 \\
(0.705754 \pm 15.5652)\end{array}$ & $\begin{array}{c}0.0184913+ \\
0.0042492\end{array}$ & 8.81434 & 3 & 3.32352 & 0.032 \\
\hline & 72 & 20 & $\begin{array}{c}6.89081 \\
(23.1837 \pm 0.718409)\end{array}$ & $\begin{array}{c}0.0219155+ \\
0.0046546\end{array}$ & 3.18390 & 3 & 5.16534 & 0.364 \\
\hline
\end{tabular}

Means sharing the same letter within each treatment is not statistically different.

and Phosphatases: Acetylcholine-esterases (AChE), alkaline phosphatases (AKP) and Acid phosphatases (ACP) (Table 5). Maximum inhibitory effect was found at $40 \mu \mathrm{g} / \mu \mathrm{l}$ concentrations on AChE enzyme activity. Maximum inhibition in AChE was induced by Deltamethrin (50\%; p-value 0.002$)$ followed by Permethrin (42\%; p-value 0.04) and then Cypermethrin (39\%; p-value 0.01), respectively. DDVP showed minimum inhibition (38.33\%; p-value 0.02 ) as shown in Table 4. Overall, a negative pattern of inhibition of

Table 3. Evaluation of resistance of commonly used pyrethroid and organophosphate insecticides in M. domestica.

\begin{tabular}{|c|c|c|c|c|c|c|}
\hline Insecticide & Expo time & $\mathrm{LD}_{50} \mu \mathrm{g} / \mu \mathrm{l}$ & $95 \% \mathrm{CL}$ & Slope $\pm \mathrm{S} . \mathrm{E}$ & $\chi^{2}(\mathrm{df})$ & $\mathrm{RR}$ \\
\hline \multirow{4}{*}{$\begin{array}{c}\text { Cypermethrin } \\
(1.5 \% \mathrm{EC})\end{array}$} & $\mathrm{F} 1$ & 29.569 & $25.4618 \pm 35.4077$ & $0.0337 \pm 0.0043$ & $36.975(3)$ & 1.1059 \\
\cline { 2 - 7 } & $\mathrm{F} 2$ & 32.702 & $28.0691 \pm 39.6412$ & $0.0325 \pm 0.0044$ & $39.203(3)$ & 1.1785 \\
\cline { 2 - 7 } & $\mathrm{F} 3$ & 36.237 & $31.0452 \pm 44.3310$ & $0.0322 \pm 0.0044$ & $41.446(3)$ & 1.225 \\
\hline \multirow{3}{*}{$\begin{array}{c}\text { Deltamethrin }(1.5 \% \\
\text { EC) }\end{array}$} & $\mathrm{F} 1$ & 42.812 & $33.8007 \pm 62.2903$ & $0.02054 \pm 0.0042$ & $2.3702(3)$ & 1.034 \\
\cline { 2 - 7 } & $\mathrm{F} 2$ & 44.283 & $35.2119 \pm 63.4279$ & $0.02148 \pm 0.0043$ & $3.5138(3)$ & 1.1283 \\
\hline \multirow{3}{*}{$\begin{array}{c}\text { Permethrin } \\
(0.5 \% \text { WP })\end{array}$} & $\mathrm{F} 3$ & 50.619 & $39.7502 \pm 74.8780$ & $0.02107 \pm 0.0043$ & $7.1524(3)$ & 1.182 \\
\cline { 2 - 7 } & $\mathrm{F} 1$ & 58.258 & $44.6974 \pm 91.8373$ & $0.02006 \pm 0.0045$ & $6.7721(3)$ & 1.299 \\
\hline \multirow{2}{*}{$\begin{array}{c}\text { DDVP } \\
(50 \% \mathrm{FC})\end{array}$} & 75.726 & $54.9657 \pm 140.532$ & $0.0181 \pm 0.00488$ & $2.3847(3)$ & 1.256 \\
\cline { 2 - 7 } & $\mathrm{F} 2$ & 85.137 & $61.0016 \pm 165.704$ & $0.01960 \pm 0.00548$ & $2.3847(3)$ & 1.461 \\
\hline
\end{tabular}


a)

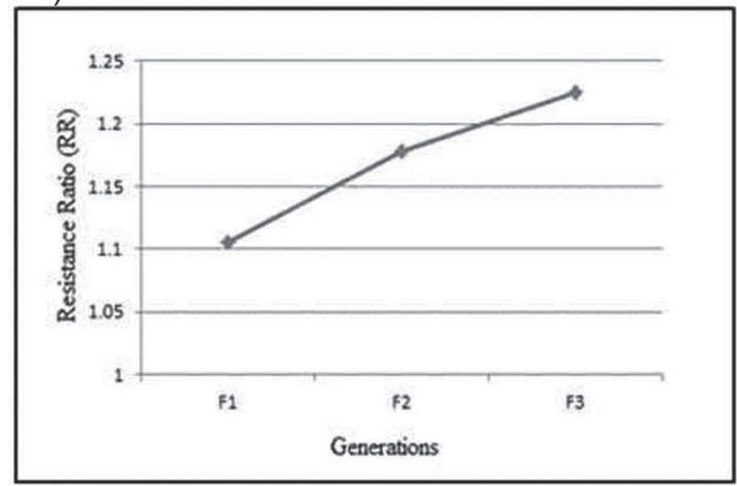

c)

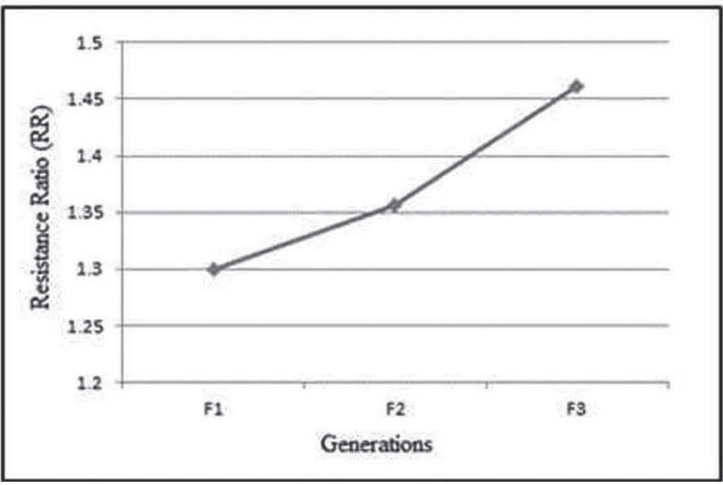

b)

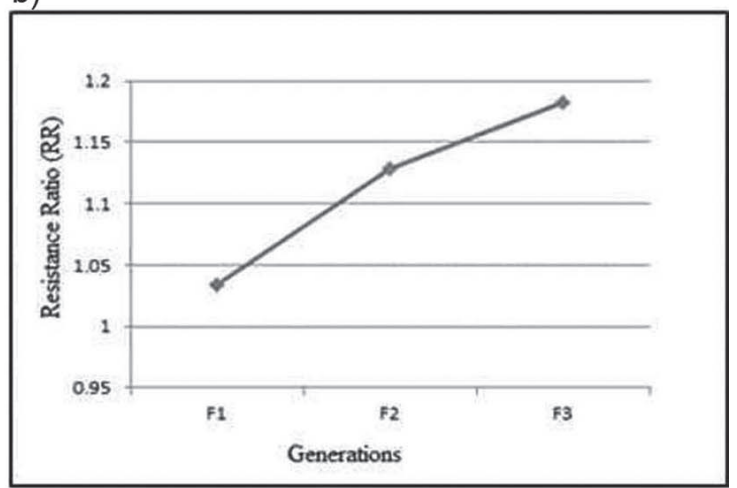

d)

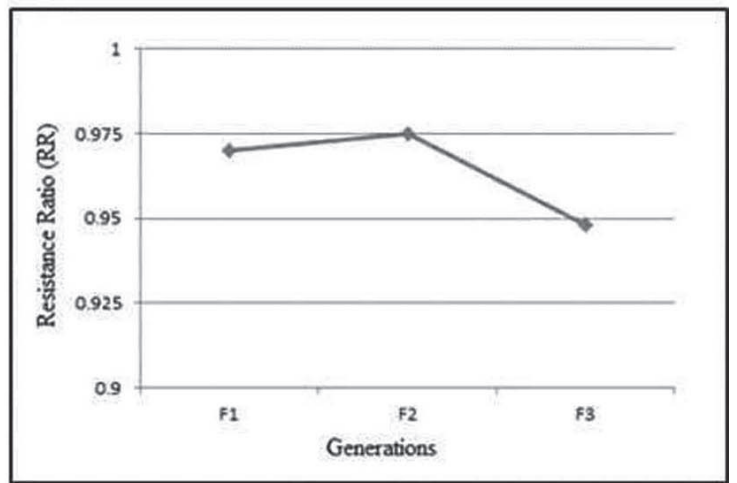

Fig. 2. The resistance ratio in successive F1, F2, and F3 generations of $M$. domestica. a) Resistance ratio increased from 1.1059 to 1.2254 in successive generation against Cypermethrin, b) Resistance ratio increased from 1.0343 to 1.1283 I successive generations against Deltamethrin, c) Resistance ratio increased from 1.2998 to 1.4615 in each successive generations of $M$. domestica, d) Resistance ratio does not increase in case of DDVP; a slight decrease in RR value 0.975 to 0.948 is shown in successive generations of $M$. domestica.

acid phosphatases was observed with Cypermethrin, Deltamethrin, and Permethrin, respectively. All the tested pyrethroid insecticides showed similar levels of reduction in AKP activity (21.167\%) at $40 \mu \mathrm{g} / \mu \mathrm{l}$ concentrations. Moreover, DDVP caused $13 \%$ of AKP inhibitory activity. Although, increased concentration caused decreases in inhibitory activity against Deltamethrin, Cypermethrin, and Permethrin. However,

Table 4. Mean adult emergence and percent progeny inhibition of $M$. domestica against commonly used pyrethroid and organophosphate insecticides.

\begin{tabular}{|c|c|c|c|c|c|c|c|}
\hline \multirow{3}{*}{$\begin{array}{l}\mathrm{Sr} \\
\text { No. }\end{array}$} & \multirow{3}{*}{ Insecticide } & \multicolumn{6}{|c|}{ Concentrations $\mu \mathrm{g} / \mu \mathrm{l}$} \\
\hline & & \multicolumn{2}{|c|}{$2.5 \mu \mathrm{g} / \mu \mathrm{l}$} & \multicolumn{2}{|c|}{$10 \mu \mathrm{g} / \mu \mathrm{l}$} & \multicolumn{2}{|c|}{$40 \mu \mathrm{g} / \mu 1$} \\
\hline & & $\begin{array}{c}\text { Percent } \\
\text { Emergence }\end{array}$ & $\begin{array}{l}\text { Percent } \\
\text { Inhibition }\end{array}$ & $\begin{array}{c}\text { Percent } \\
\text { Emergence }\end{array}$ & $\begin{array}{l}\text { Percent } \\
\text { Inhibition }\end{array}$ & $\begin{array}{c}\text { Percent } \\
\text { Emergence }\end{array}$ & $\begin{array}{l}\text { Percent Inhibi- } \\
\text { tion }\end{array}$ \\
\hline \multirow{2}{*}{1} & \multirow{2}{*}{ Cypermethrin } & $41.67 \pm 2.89 \mathrm{a}$ & $58.33 \pm 2.89 \mathrm{~b}$ & $28.67 \pm 2.89 \mathrm{~b}$ & $73.33 \pm 2.89 \mathrm{a}$ & $20.00 \pm 0.00 \mathrm{~b}$ & $80.00 \pm 0.00 \mathrm{a}$ \\
\hline & & \multicolumn{6}{|c|}{$(1.5 \% \mathrm{EC})$} \\
\hline \multirow{2}{*}{2} & \multirow{2}{*}{$\begin{array}{c}\text { Deltamethrin } \\
(1.5 \% \mathrm{w} / \mathrm{v})\end{array}$} & $51.67 \pm 2.89 \mathrm{a}$ & $48.33 \pm 2.89 \mathrm{c}$ & $36.67 \pm 2.89 \mathrm{~b}$ & $63.33 \pm 2.89 \mathrm{~b}$ & $25.00 \pm 5.00 \mathrm{c}$ & $75.00 \pm 5.00 \mathrm{a}$ \\
\hline & & \multicolumn{6}{|c|}{$(\mathrm{F}=73.40 ;$ d.f $=2 ; \mathrm{P}<0.05)$} \\
\hline \multirow{2}{*}{3} & \multirow{2}{*}{$\begin{array}{l}\text { Permethrin } \\
(0.5 \% \mathrm{WP})\end{array}$} & $46.67 \pm 2.89 \mathrm{a}$ & $53.33 \pm 2.89 \mathrm{~b}$ & $38.33 \pm 2.89 \mathrm{~b}$ & $61.67 \pm 2.89 \mathrm{~b}$ & $19.33 \pm 5.77 \mathrm{c}$ & $80.67 \pm 5.77 \mathrm{a}$ \\
\hline & & \multicolumn{6}{|c|}{$(\mathrm{F}=95.17 ;$ d.f $=2 ; \mathrm{P}<0.05)$} \\
\hline \multirow{2}{*}{4} & \multirow{2}{*}{$\begin{array}{c}\text { DDVP } \\
(50 \% \text { EC) }\end{array}$} & $41.67 \pm 2.89 \mathrm{a}$ & $59.33 \pm 2.89$ & $26.67 \pm 2.89 \mathrm{a}$ & $73.33 \pm 2.89$ & $17.67 \pm 2.52 \mathrm{~b}$ & $82.33 \pm 2.52$ \\
\hline & & \multicolumn{6}{|c|}{$(\mathrm{F}=62.74 ;$ d.f $=2 ; \mathrm{P}<0.05)$} \\
\hline
\end{tabular}

$\mathrm{EC}=$ emulsified concentration, $\mathrm{WP}=$ Wettable Powder, $\mathrm{W} / \mathrm{V}=$ weight by Volume

$\mathrm{P}<0.001=$ highly significant, $\mathrm{P}<0.01=$ highly significant, $\mathrm{P}<0.05=$ significant, $\mathrm{P}>0.05=\mathrm{N}$

Means sharing the same letter within each treatment is not statistically different. 
DDVP showed a positive correlation as increasing the concentration also increased inhibitory activity (Table 5).

House fly has a great ability to develop resistance to insecticides $[10,32]$. The intensive use of pyrethroids for its control has led to many instances of pyrethroid resistance worldwide $(19,22)$. Monitoring of insecticide resistance through bioassays helps recognize a particular resistant insecticide in order to devise a management strategy $[10,13,14,15,32]$ that lessens resistance development. The present work was focussed on evaluating the resistance level in house fly against frequently used insecticides in Faisalabad, Pakistan and to add to our knowledge of resistance in general. Five different concentrations of insecticides were used following the protocol of Khan [32] and it was observed that increased concentration caused increased mortality, which is in agreement with the findings of Farooq \& Fareed [40]. Farooq \& Fareed [40] employed nine commonly used different insecticides and found concentration -dependent response for each insecticide. Similarly, increased exposure time also caused increased mortality [41]. DDVP showed highest mean mortality (100\%), whereas, lowest mean mortality was observed against Permethrin (73.80\%).

Monitoring the susceptibility status of insecticides is an important tool to improve the use of existing insecticides and otherwise to induce the delay in the development of insecticide resistance. It has been reported that resistance towards pyrethroid group of insecticides mainly Permethrin, Cypermethrin, and Deltamethrin was found to be comparatively high [31, 37]. In our study, the resistance bioassay was performed to the third generation of house fly, $M$. domestica at 48 hours (F1, F2, and F3). The data show a progressive increase in resistance to Cypermethin, Deltamethrin and Permethrin, but very low or no resistance was observed against DDVP. This group of insecticides, is being used separately or in combination with pyrethroids for the control of $M$. domestica [31, 37, 42, 43]. In addition, high resistance was found in Permethrin with a RR of 1.461 in the third generation followed by Cypermethrin and Deltamethrin, respectively $(\mathrm{RR}=1.22$ and 1.1820$)$. Subsequently, an increase in the resistance ratio was observed in successive generations of $M$. domestica [32]. Interestingly, DDVP showed a slight decrease in the resistance ratio in successive generations.

The objectives of an insect pest management strategy can be immediate control of insect pest or the inhibition of its progeny production. Previously, it was reported by Tunaz et al. [28] and Castro et al. [44] that insecticide affects the population emergence either by suppressing oviposition or induced inhibition in adult emergence though developmental delay from larvae to pupae or pupae to adult in $M$. domestica. The toxic component present in the insecticide subsequently affects the biochemical process that ultimately influences the embryonic development and inhibition of adult emergence in F1 progeny [45]. Additionally, the

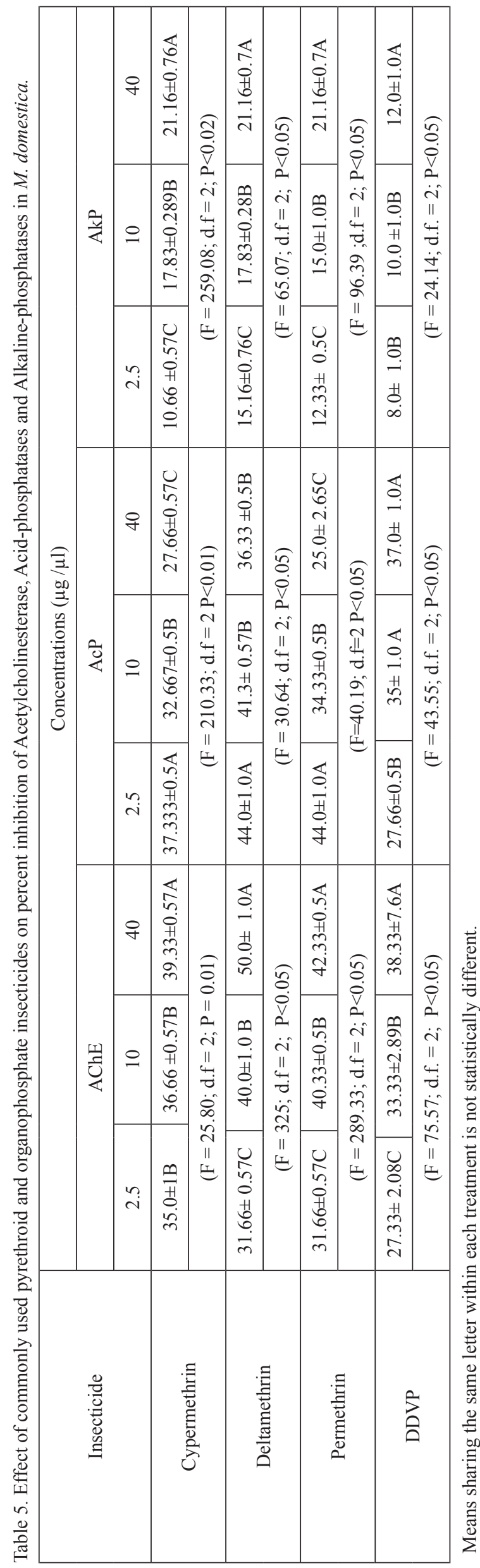


application of some insecticides to last instar larvae causes disturbance in larval/pupal transformation, which leads to prolongation of last larval instar [40, 4649]. Farooq \& Fareed [40] studied different biological parameters against nine insecticides in $M$. domestica and found that with the exception of larval duration, developmental parameters were significantly $(P>0.05)$ altered in a concentration-dependent manner for each insecticide. Similarly, in the present findings, DDVP was found to cause a maximum developmental delay in F1 progeny, which is also in agreement to studies by Schneider et al. [49, 50].

Insecticide resistance in house fly is reported to be linked with the differential expression of certain genes encoding metabolic detoxification enzymes [51]. Thereby, the enzymatic profiles are modulated in response to various insecticides. Acetylcholinesterase (AChE) serves as a target site for the major group of insecticides, organophosphate (OP) and carbamate compound [23, 52]. Resistance to organophasphates and carbamate insecticides is due to mutations in the Acetylcholinesterase gene (Ace) [51, 53]. Moreover, binary combinations of organophosphate and synthetic pyrethroids are reported as more potent acetylcholinesterase inhibitors than organophosphate and carbamate mixtures [54]. Organophosphate resistance is mainly mediated by enhanced metabolic detoxification through quantitative changes in esterases [55]. Farooq \& Fareed [40] studied biochemical parameters in $M$. domestica and found enzymatic modulation in the activity of glutathione S-transferases, total esterases, acetylcholinesterase, and acid and alkaline phosphates for each insecticide, which ultimately contributes to the development of resistance. Resistant larvae exhibited higher activities of esterases and phosphatases compared to susceptible larvae [11]. The current findings showed that Deltamethrin inhibited maximum percent activity of AChE (50\%) followed by Permethrin (42.33\%), Cypermethrin and DDVP, respectively. Similarly, Deltamethrin, Cypermethrin and Permethrin also caused inhibitory effects on Alkaline-Phosphatases activity (AKP). Interestingly, DDVP showed low AKP inhibitory activity (13\%). Here we showed a negative effect of insecticides on Acid phosphatases inhibitory activity. Increase in concentration caused decreased enzyme inhibition activity. Maximum inhibition of acid phosphatases activity was obtained by DDVP (37\%). In the case of other three tested insecticides, with an increase in concentration the inhibitory activity was reduced [22]. Deltamethrin induced reduction of enzyme activity followed by Cypermethrin and Permethrin. The current results, thus, supports the notion that decreased rate of detoxifying enzymes was responsible for imparting the susceptibility to $M$. domestica against applied insecticides which is consistent to the previous studies described by Farooq \& Freed et al. [40], Smirle et al. [23] and Walsh et al. [24].
Thus, in order to manage the resistance level in house fly, it is suggested that pyrethroid insecticides should be used carefully and preferably in combination with organophosphate groups of insecticides.

\section{Conclusions}

Highest mean mortality, lowest resistance ratio (RR) and maximum inhibition in adult emergence was found with DDVP. The inhibitory activity of the esterases, Acetylcholine and Phosphatases; ACP and AKP showed that Deltamethrin inhibited maximum activity of AChE (50\%), whereas, DDVP caused maximum inhibition of acid phosphatases. In conclusion, house fly populations are more resistant to pyrethroids compared to organophosphate insecticides.

\section{Acknowledgements}

The facilities provided by Department of Zoology, Government College University Faisalabad (GCUF) are greatly appreciated. All authors declare that they have no competing interests.

\section{References}

1. ABBAS N., KHAN H.A.A., SHAD S.A. Cross-resistance, genetics, and realized heritability of resistance to fipronil in the house fly, Musca domestica (Diptera: Muscidae) a potential vector for disease transmission. Parasitol Res. 113 (4), 1343, 2014.

2. FOTEDAR R. Vector potential of house flies (Musca domestica) in the transmission of Vibrio cholerae in India. Acta Tropica, 78 (1), 31, 2001.

3. MALIK A.,SINGH N., SATYAS. House fly (Musca domestica): a review of control strategies for a challenging pest. J Env Sci Health Part B, 42 (4), 453, 2007.

4. ALBARRAK A.S. Comparative studies on house fly, Musca domestica, population in different animal farms in relation to attractants and control at Hail Province, Saudi Arabia. Pak Entomol, 31, 142-147, 2009.

5. HALD B., SKOVGÅRD H., PEDERSEN K., BUNKENBORG H. Influxed insects as vectors for Campylobacter jejuni and Campylobacter coli in Danish broiler houses. Poultry Sci, 87 (7), 1428, 2008.

6. JENSEN E. Banning neonicotinoids: Ban first, ask questions later. Seattle J Env, 5, 2015.

7. PETER J.V., SUDARSAN T.I., MORAN J.L. Clinical features of organophosphate poisoning: A review of different classification systems and approaches. Peerreviewed, official publication of Indian Society of Critical Care Medicine, Ind J Crit Care Med, 18 (11), 735, 2014.

8. LUO Y., ZHANG M. Environmental modeling and exposure assessment of sediment-associated pyrethroids in an agricultural watershed. PloS One, 6 (1), 15794, 2011.

9. LAU K.W., CHEN C.D., LEE H.L., NORMA-RASHID Y., SOFIAN-AZIRUN M. Evaluation of insect growth regulators against field-collected Aedes aegypti and Aedes 
albopictus (Diptera: Culicidae) from Malaysia. J Med Ent, 52 (2), 199, 2015.

10. KHAN H.A.A., AKRAM W., KHAN T., HAIDER M.S., IQBAL N., ZUBAIR M. Risk assessment, cross-resistance potential, and biochemical mechanism of resistance to emamectin benzoate in a field strain of house fly (Musca domestica Linnaeus). Chemosphere, 151, 133, 2016.

11. SIMMONS C.P., GONCALVES N.S., GHAEMMAGHAMI M., BAJAJ-ELLIOTT M., CLARE S., NEVES B. MACDONALD T.T. Impaired resistance and enhanced pathology during infection with a noninvasive, attaching-effacing enteric bacterial pathogen, Citrobacter rodentium, in mice lacking IL-12 or IFN- $\gamma$. J Immunol, 168 (4), 1804, 2002.

12. DMOCHOWSKA-SLEZAK, K., GIEJDASZ, K., FLISZKIEWICZ, M., ZOLTOWSKA, K. Variations in antioxidant defense during the development of the solitary bee Osmia bicornis. Apidologie, 46 (4), 432, 2015.

13. PAVELA R., MAGGI F., LUPIDI G., MBUNTCHA H., WOGUEM V., WOMENI H.M., BENELLI G. Clausena anisata and Dysphania ambrosioides essential oils: from ethno-medicine to modern uses as effective insecticides. Env Sci Pollution Res, 1-11, 2018.

14. MEMMI B.K. Mortality and knockdown effects of imidacloprid and methomyl in house fly (Musca domestica L., Diptera: Muscidae) populations. J Vect Ecol, 35(1), 144-148, 2010.

15. MALATHI V.M., JALALI S.K., GOWDA D.K.S., MOHAN M., VENKATESAN T. Establishing the role of detoxifying enzymes in field-evolved resistance to various insecticides in the brown planthopper (Nilaparvata lugens) in South India. Insect Sci, 24 (1), 35, 2017.

16. YANOLA J., SOMBOON P., WALTON C., NACHAIWIENG W., PRAPANTHADARA L.A. A novel F1552/C1552 point mutation in the Aedes aegypti voltagegated sodium channel gene associated with permethrin resistance. Pesticide Biochem Physiol, 96 (3), 127, 2010.

17. SCOTT J.G., LIU N., KRISTENSEN M., CLARK A.G. A case for sequencing the genome of Musca domestica (Diptera: Muscidae). J Med Ent, 46 (2), 175, 2009.

18. GOMES B., PURKAIT B., DEB R.M., RAMA A., SINGH R.P., FOSTER G.M., COLEMAN M., KUMAR V., PAINE M., DAS P., WEETMAN D. Knockdown resistance mutations predict DDT resistance and pyrethroid tolerance in the visceral leishmaniasis vector Phlebotomus argentipes. PLoS Neglected Trop Dis, 11 (4), e0005504, 2017.

19. SCOTT J.G. Evolution of resistance to pyrethroid insecticides in Musca domestica. Pest Management Sci, 73 (4), 716, 2017.

20. TRIPATHI R.K., O'BRIEN R.D. Insensitivity of acetylcholinesterase as a factor in resistance of house flies to the organophosphate Rabon. Pest Biochem Physiol, 3 (4), 495, 1973.

21. KASAI S., SUN H., SCOTT J.G. Diversity of knockdown resistance alleles in a single house fly population facilitates adaptation to pyrethroid insecticides. Insect Mol Bio, 26 (1), 13, 2017.

22. PANINI M., MANICARDI G.C., MOORES G.D., MAZZONI E. An overview of the main pathways of metabolic resistance in insects. Invertebrate Survival J, 13, 326, 2016.

23. SMIRLE M.J., ZUROWSKI C.L., LOWERY D.T., FOOTTIT R.G. Relationship of insecticide tolerance to esterase enzyme activity in Aphispomi and Aphis spiraecola (Hemiptera: Aphididae). J Econ Ent, 103 (2), 374, 2010.

24. WALSH S.B., DOLDEN T.A., MOORES G.D., KRISTENSEN M., LEWIS T., ALAN L., WILLIAMSON M.S. Identification and characterization of mutations in housefly ( $M$. domestica) acetylcholinesterase involved in insecticide resistance. Biochem J, 359 (1), 175, 2001.

25. MORIYAS K., FUJIBAYASHI T., YOSHIHARA T., MATSUDA A., SUMI N., UMEZAKI N., WATANABE H. Verotoxin-producing Escherichia coli 157: H7 carried by the house fly in Japan. Med Vet Ent, 13 (2), 214, 1999.

26. NATHAN S.S., CHUNG P.G., MURUGANK. Effect of botanical insecticides and bacterial toxins on the gut enzyme of the rice leaf folder Cnaphalocrocis medinalis. Phytoparasit, 32 (5), 433, 2004.

27. SRINIVAS R., UDIKERI S.S., JAYALAKSHMI S.K., SREERAMULU K. Identification of factors responsible for insecticide resistance in Helicoverpa armigera. Comp Biochem Physiol Part C: Toxicol Pharm, 137 (3), 261, 2004.

28. TUNAZ H., UYGUNN. Insect growth regulators for insect pest control. Turk J Agri Forestry, 28 (6), 377, 2004.

29. AL-DEEB M.A. Pyrethroid insecticide resistance kdr gene in the house fly, Musca domestica (Diptera: Muscidae), in the United Arab Emirates. Agri Sci, 5 (14), $1522,2014$.

30. SINGH O.P., BALI P., HEMINGWAY J., SUBBARAO S.K., DASH A.P., ADAK T. PCR-based methods for the detection of L1014 kdr mutation in Anopheles culicifacies sensu lato. Malaria J, 8 (1), 154, 2009.

31. KAUFMAN P.E., NUNEZ S.C., MANN R.S., GEDEN C.J., SCHARFM.E. Nicotinoid and pyrethroid insecticide resistance in house flies (Diptera: Muscidae) collected from Florida dairies. Pest Management Sci, 66 (3), 290, 2010.

32. KHAN H.A.A., AKRAM W., SHAD S.A., LEE J.J. Correction: Insecticide Mixtures Could Enhance the Toxicity of Insecticides in a Resistant Dairy Population of Musca domestica L. PloS one, 8 (8), 2013.

33. FINNEYD. J. Probit analysis; a statistical treatment of the signoid respoce curve. Cambridge University Press, No. 519.9 F55, 1962.

34. ABBOTT W.S. A method of computing the effectiveness of an insecticide. J Econ Entomol, 18 (2), 265, 1925.

35. ACEVEDO G.R., ZAPATER M., TOLOZA A.C. Insecticide resistance of house fly, Musca domestica (L.) from Argentina. ParasitolRes, 105 (2), 489, 2009.

36. SINGH S., PRAKASH S. Development of resistance in Tribolium castaneum, Herbst (Coleoptera: Tenebrionidae) towards deltamethrin in laboratory. Int J Sci Res Pub, 3 (8), 1, 2013.

37. AZHAR H., KHAN A., AKRAM W., SHAD S.A. Resistance to conventional insecticides in Pakistani populations of Musca domestica L. (Diptera: Muscidae): apotential ectoparasite of dairy animals. Ecotoxicol, 22 (3), 522, 2013.

38. CETIN H., ERLER F., YANIKOGLUA. Survey of insect growth regulator (IGR) resistance in house flies (Musca domestica L.) from south western Turkey. J VecEcol, 34 (2), 329, 2009.

39. YOUNES S.B., SAYADI S. Purification and characterization of a novel trimeric and thermo tolerant laccase produced from the Ascomycetes cytalidium thermophilum strain. J Mol Catalys B: Enzym, 73 (1), 35, 2011.

40. FAROOQ M., FREED S. Mortality, Biological, and Biochemical Response of Musca domestica (Diptera: 
Muscidae) to Selected Insecticides. J Entomol Sci, 53 (1), 27, 2018.

41. RAMA A., KESARI S., DAS P., KUMAR V. Studying DDT susceptibility at discriminating time intervals focusing on maximum limit of exposure time survived by DDT resistant phlebotomus argentipes (Diptera: Psychodidae): an Investigative Report. Japanese J Infect Dis, 70 (4), 437, 2017.

42. SHAD S.A., SAYYED A.H., FAZAL S., SALEEM M.A., ZAKA S.M., ALI M. Field evolved resistance to carbamates, organophosphates, pyrethroids, and new chemistry insecticides in Spodoptera litura Fab. (Lepidoptera: Noctuidae). J Pest Sci, 85 (1), 153, 2012.

43. TONG H., SU Q., ZHOU X., BAI L. Field resistance of Spodoptera litura (Lepidoptera: Noctuidae) to organophosphates, pyrethroids, carbamates and four new chemistry insecticides in Hunan, China. J Pest Sci, 86 (3), 599, 2013.

44. CASTRO A.A., LACERDA M.C., ZANUNCIO T.V., RAMALHO F.D.S., POLANCZYK R.A., SERRAO J.E., ZANUNCIO J.C. Effect of the insect growth regulator diflubenzuron on the predator Podisus nigrispinus (Heteroptera: Pentatomidae). Ecotoxicol, 21 (1), 96, 2012.

45. KHAN H.A.A., AKRAM W., SHEHZAD K., SHAALAN E.A. First report of field evolved resistance to agrochemicals in dengue mosquito, Aedes albopictus (Diptera: Culicidae), from Pakistan. Paras Vect, 4 (1), 146, 2011.

46. FOGEL M.N., SCHNEIDER M.I., RIMOLDI F., LADUX L.S., DESNEUX N., RONCO A.E. Toxicity assessment of four insecticides with different modes of action on pupae and adults of Eriopis connexa (Coleoptera: Coccinellidae), a relevant predator of the Neotropical Region. Env Sci Pollution Res, 23 (15), 14918, 2016.

47. RAUSCHENBACH I.Y., Changes in juvenile hormone and ecdysteroid content during insect development under heat stress. In Hormones and Metabolism in Insect Stress (pp. 115-148). CRC Press 2018.
48. WANG J., ZHOU H.Y., ZHAO Z.M., LIU Y.H. Effects of juvenile hormone analogue and ecdysteroid on adult eclosion of the fruit fly Bactrocera minax (Diptera: Tephritidae). J Econ Ent, 107 (4), 1519, 2014.

49. FAROOQ M, FREED S. Combined effects of Beauveria bassiana (Hypocreales: Clavicipitaceae) and insecticide mixtures on biological parameters of Musca domestica (Diptera: Muscidae). Pak J Zool, 48, 1465, 2016.

50. SCHNEIDER M.I., SMAGGHE G., PINEDA S., VINUELAE. Action of insect growth regulator insecticides and spinosadon life history parameters and absorption in third-instar larvae of the endoparasitoid Hyposoter didymator. Biolog Cont, 31 (2), 189, 2004.

51. HOJLAND D.H., KRISTENSEN M. Analysis of differentially expressed genes related to resistance in spinosad-and neonicotinoid-resistant Musca domestica L. (Diptera: Muscidae) Strains. PloS one, 12 (1), e0170935, 2017.

52. SAMEER H.Q., ABDEL-FATTAH N.A.H., SHEHAWY A.A. Assessment of DNA damage and biochemical responses in Rhyzopertha dominica exposed to some plant volatile oils. J Pharm Toxicol, 12, 87, 2017.

53. KOZAKI T., BRADYAND S.G., SCOTT G.J. Frequencies and evolution of organophosphate insensitive acetylcholinesterase alleles in laboratory and field populations of the house fly, Musca domestica L. Pesticide Biochem Physiol, 95, 6, 2009.

54. ARORA S., BALOTRA S., PANDEY G., KUMAR A. Binary combinations of organophosphorus and synthetic pyrethroids are more potent acetylcholinesterase inhibitors than organophosphorus and carbamate mixtures: an in vitro assessment. Toxicollett, 268, 8, 2017.

55. ZHANG Y., LI J., MA Z., SHAN C., GAO X. Multiple mutations and overexpression of the MdaE7 carboxylesterase gene associated with male-linked malathion resistance in house fly, Musca domestica (Diptera: Muscidae). Scientific Reports, 8 (1), 224, 2018. 